\title{
VARIABLE RELATIONSHIPS AMONG DIFFERENT SCIENCE LEARNERS IN ELEMENTARY SCIENCE-METHODS COURSES
}

Erratum to: Int J of Sci and Math Educ 2009

DOI 10.1007/s10763-007-9121-8

Bleicher, R. E. (2009). Variable Relationships Among Different Science Learners in Elementary Science-methods Courses. International Journal of Science and Mathematics Education 7:293-313.

Due to a technical error, the name and address of the second author has been deleted during the production of the article. The names of the authors should read:

Bleicher, R. E. \& Lindgren, J. (2009). Variable Relationships Among Different Science Learners in Elementary Science-methods Courses. International Journal of Science and Mathematics Education 7:293-313.

The addresses:

Robert E. Bleicher

California State University Channel Islands

1 University Drive, Camarillo, CA, 93012, USA

E-mail: Bob.bleicher@csuci.edu

Joan S. Lindgren

Florida Atlantic University

MC-12, 207E, Jupiter, FL, 3345, USA

E-mail: jlindgre@fau.edu

The online version of the original article can be found at http://dx.doi.org/10.1007/s10763-007-9121-8. 